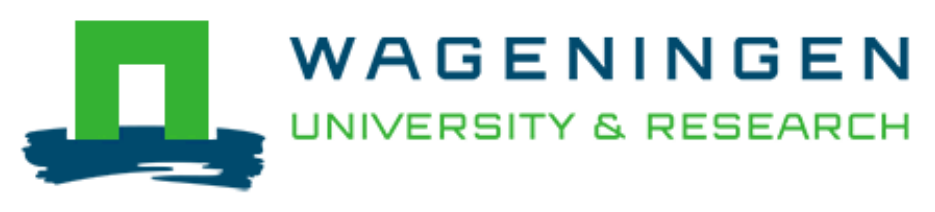

\author{
A moral householding perspective on the sharing economy \\ Laamanen, M., Wahlen, S., \& Lorek, S.
}

This is a "Post-Print" accepted manuscript, which has been published in "Journal of Cleaner Production"

This version is distributed under a non-commercial no derivatives Creative Commons (c) (1) (\$) $\Theta$

(CC-BY-NC-ND) user license, which permits use, distribution, and reproduction in any medium, provided the original work is properly cited and not used for commercial purposes. Further, the restriction applies that if you remix, transform, or build upon the material, you may not distribute the modified material.

Please cite this publication as follows:

Laamanen, M., Wahlen, S., \& Lorek, S. (2018). A moral householding perspective on the sharing economy. J ournal of Cleaner Production, 202, 1220-1227. DOI:

10.1016/j.jclepro.2018.08.224

You can download the published version at:

https://doi.org/10.1016/j.jclepro.2018.08.224 


\section{Accepted Manuscript}

A moral householding perspective on the sharing economy

Mikko Laamanen, Stefan Wahlen, Sylvia Lorek

PII:

S0959-6526(18)32573-3

DOI:

10.1016/j.jclepro.2018.08.224

Reference:

JCLP 14008

To appear in:

Journal of Cleaner Production

Received Date:

01 December 2017

Accepted Date:

20 August 2018

Please cite this article as: Mikko Laamanen, Stefan Wahlen, Sylvia Lorek, A moral householding perspective on the sharing economy, Journal of Cleaner Production (2018), doi: 10.1016/j.jclepro. 2018.08.224

This is a PDF file of an unedited manuscript that has been accepted for publication. As a service to our customers we are providing this early version of the manuscript. The manuscript will undergo copyediting, typesetting, and review of the resulting proof before it is published in its final form. Please note that during the production process errors may be discovered which could affect the content, and all legal disclaimers that apply to the journal pertain. 


\section{A moral householding perspective on the sharing economy}

Mikko Laamanen ${ }^{1}$, Stefan Wahlen [corresponding author] ${ }^{2}$ and Sylvia Lorek ${ }^{3}$

${ }^{1}$ School of Management, Royal Holloway University of London, Egham, Surrey, TW20 0EX, United Kingdom, +44 (0) 1784 276100, mikko.laamanen@,rhul.ac.uk

${ }^{2}$ Wageningen University \& Research, Sociology of Consumption and Households,

Hollandseweg 1, 6706 KN Wageningen, The Netherlands, +31 (0) 317482186 , stefan.wahlen@wur.nl

${ }^{3}$ Sustainable Europe Research Institute, Schwimmbadstr. 2e, 51491 Overath, Germany, +49 2206 84848, sylvia.lorek@t-online.de

\section{Conflicts of interest}

None

\section{Funding}

This research did not receive any specific grant from funding agencies in the public, commercial, or not-for-profit sectors. 


\title{
A moral householding perspective on the sharing economy
}

\begin{abstract}
In this paper, we scrutinise the sharing economy from a moral householding perspective and evaluate the moral justifications for a sustainable form of the sharing economy. We consider the emergence of normative moral justifications through householding practices that rest on local mobilisation of people in defence of communities and commitments against the adverse impacts of neoliberal market capitalism. Our perspective draws on Karl Polanyi's conceptualisation of householding, that is, autarchic, communistic provision in a closed community. Using timebanking as an example, we illustrate how a moral sharing economy can be mobilised in collective battles against the current neoliberal system of economic crisis. We contribute to the amassing sharing economy literature emphasising a central, yet missing element of the current discourse: householding as practices creating self-sufficiency and autonomy as well as combining both kin and stranger.
\end{abstract}

\section{Keywords}

Moral economy; sharing economy; householding; Polanyi; mobilisation; timebanking 


\section{Introduction}

A paradoxical combination of community optimism and commercial extractivism features prominently in the so-called sharing economy (e.g. Bardhi and Eckhardt, 2012; Cheng, 2016; Frenken and Schor, 2017; Laamanen et al., 2018; Richardson, 2015; Scholz, 2017; Slee, 2015; Stephany, 2015). It reflects the central features of contemporary neoliberal capitalism: the creation of value increasingly rests on harnessing reproductive forms of labour and private, household resources to extract rent while neoliberal thinking systematically neglects non-market transactions, informal labour, and community activities beyond "the market" as viable and sustainable forms of economy (Fraser, 2016; Luxton, 2006). In this paper, we scrutinise the sharing economy from a moral householding perspective and elaborate on the mobilisation of independent, non-market, and community-based production and consumption for a sustainable sharing economy. We ask: What are the moral justifications for householding practices for a more sustainable sharing economy? Our argumentation builds upon two central concepts: the moral economy and householding. We use them to dissect sharing, respectively the sharing economy, using timebanking as a case example.

The concept of moral economy offers a critique of neoliberal economic thinking and a theoretical lens to elaborate on the moral justifications of economic activity (cf. Amable, 2011; Bolton and Laaser, 2013; Sayer, 2007). The moral economy acknowledges values, sentiments, and practices in the civil society emphasising the social desirability and altruistic meaning of economic interaction (Cheal, 1989; Götz, 2015). This stands in stark contrast to a capitalist growth paradigm that rests on increasing corporate power and governmental support for neoliberal policies of free competition and privatisation of common, public good. Likewise, our perspective builds 
on Karl Polanyi's (2001) conceptualisation of householding as production for one's own use in (semi-)autonomous communities (Halperin, 1991; Polanyi, 1957; Sahakian, 2017; Stanfield, 1986). Community supporting and sustaining householding practices include, amongst others, minding children, sick, and elderly people; washing, cooking, and cleaning; do-it-yourself jobs such as repair, maintenance, and building; the organisation and supervision of household tasks; subsistence agriculture; transport; voluntary work in civil society organisations, and even help in family businesses (e.g. Halperin, 1991; Jalas and Juntunen, 2015; Spangenberg and Lorek, 2002).

In his book "The Great Transformation", Polanyi elaborates on the relation between moral human institutions and the market economy. A way to approach this separation and tensional co-existence of moral institutions and markets is through the moral economy concept, which focusses on the normative moral justifications of economic action (Fitzmaurice et al., 2018). We theorise the emergence of normative moral justifications through the alternative practices of householding. Moralising consumption and production - placing moral judgement on the practices in and of themselves (cf. Germann Molz, 2013) - is not part of the approach. Rather, moral justification emerges from the local mobilisation of people defending their communities and commitments against the adverse impacts of the neoliberal market capitalism.

In order to contextualise our moral economy perspective on householding, we elaborate on a particular initiative in the wider confines of the sharing economy. We concentrate on the complementary currency system of timebanking, a communitybased, collaborative network sharing production and consumption. Householding practices here provide immediate care and livelihood as well as impact collective wellbeing through the generation of a common good. Timebanks are particularly prominent where neoliberal politico-economic policies render local conditions austere and 
precarious. The moral justifications discussed later on are based on a close reading of research in the field of complementary currencies as well as on-going fieldwork in the context of a Northern European timebank in Helsinki. The Helsinki Timebank is the largest in Finland, active since 2009, and a fixture in several sharing economy discussions in the country. We point out, how timebanking challenges dominant institutions through its alternative structure and practice, which we identify as resistance founded on householding.

We contribute to the amassing sharing economy literature by emphasising a central, yet missing element in the current discourse: the way in which householding practices create self-sufficiency and autonomy from the market economy through informal exchange communities combining both kin and stranger. Using householding as an analytic concept, we expose the everyday embeddedness of morality and offer a conceptualization of an everyday moral sharing economy that acknowledges normative moral justifications in community-based economy building.

The paper is structured as follows. In chapter 2 we relate and contrast moral economy to the sharing economy. Chapter 3 introduces moral economy of householding, and the way in which this becomes mobilised is examined in chapter 4. We provide the empirical example of timebanking as moral householding in the sharing economy in chapter 5 . Finally, chapter 6 concludes the paper.

\section{The moral economy and the sharing economy}

Reflecting on E. P. Thompson $(1966,1971)$, the morality of the economy finds its legitimacy in responsibilities, values and norms, and social expectations. As such, the moral constitution of economic action rests not only on 'the particular forms taken by the social relations of production, distribution, exchange, consumption, care, and mode of regulation ... [but also] constitutes normative assumptions of rights and 
responsibilities' (Sayer, 2007, p. 263). Economic institutions, interactions and practices that recognise social embeddedness and maintain equitable relations of exchange make up 'a system of transactions which are defined as socially desirable (i.e. moral)' (Cheal, 1989, p. 15) while profiteering on the needs and necessities of the people infringes on a moral legitimisation of such a system (Thompson, 1966, p. 63).

Morality in this sense of normative assumptions of social desirability is, however, not the mainstay of neoliberal economic thinking. Historically, the political economy of economic liberalism is not immoral, but deemed 'disinfested of intrusive moral imperatives' (Thompson, 1971, p. 90). Similarly, contemporary neoliberal capitalism can be regarded amoral - void of moral sensibilities - inasmuch as interdependencies between various actors and the collective good are not given centrality (Gibson-Graham, 2006). A re-moralisation of the economy is foundational for understanding the roots of controversy and antagonism within neoliberal market economy from which the sharing economy in its various guises has emerged.

In neoliberalism. free market competition is justified as the optimal and democratic means of meeting demand and supply in human societies (Amable, 2011; Harvey, 2006). Neoliberal capitalism normalises egoism, deregulation and competition, excessive work and superfluous consumption (vis-à-vis rising unemployment and lack of access to necessary provisions), widening social divides, environmental degradation, and political alienation. Individualisation, responsibilisation and commercialisation in the everyday life subject citizens and consumers to several constraints (Barnett et al., 2008; Soper, 2007) including continuous self-improvement, increasing debt, and the polarisation of societies on the basis of race, gender, and status divisions. In the neoliberal economist thinking, production and consumption are simply supply and demand functions; related, yet separate entities manifested in work and non-work, 
commodities, utility maximisation, and extraction. Neoliberalism seeps into the everyday experience by defining new regimes of work (Fleming, 2014; Laamanen et al., 2018; Moisander et al., 2018) as well as way to consume (e.g. on platforms of the commercial sharing economy; Wahlen and Laamanen, 2017).

The sharing economy emerged in this neoliberal context around the end of the 2000s and has since been touted as the morally superior "economic and social model" where colloquial sharing in communities and giving access to resources liberates people from owning as well as superfluous, unsustainable consumerism. The sharing economy is considered to encompass socially desirable economic activities that are framed complementary as well as in opposition to the dominant commercial economy: the activities either aim to add variety or enact systemic change in the current economy (Wahlen and Laamanen, 2017). Regardless of the underlying aim, the sharing economy takes a particular form of social and economic organisation; engages in sharing of practices, resources, and lifestyles on various platforms, and builds communities by creating identities and boundaries for collaborative and collective action (Bardhi and Eckhardt, 2012; Botsman and Rodgers, 2010; Cheng, 2016; Frenken and Schor, 2017; Wahlen and Laamanen, 2017). The sharing economy is considered to have changed the social dynamics of consumption and impacted sustainable development in a positive way providing alternative ways to access resources, get work done, or just rest one's head in a different town (e.g. Balaram, 2016; Botsman and Rodgers, 2010; Heinrichs, 2013).

Yet, there is increasing suspicion about the moral authority of the sharing economy (Laamanen et al., 2018; Ladegaard, 2018; Richardson, 2015; Scholz, 2017; Slee, 2015; Stephany, 2015). Sharing economy is in colloquial understanding mostly related to commercial venture capital financed sharing economy platforms, such as 
AirBnB, Uber, or Deliveroo. The literature on platform-based sharing illustrates various problems related to this economic transformation including predatory practices of extracting rent from users' input (i.e. their 'consumer work'); failing to provide sufficient protection to (providing or consuming) users, and treating workers as independent contractors and entrepreneurs. Rather than building communities, local social relations have suffered from unregulated competition, accelerated gentrification of neighbourhoods, and increased discrimination and exclusion among the users themselves.

Should we accept the sharing economy as a reaction to the neoliberalisation of society and economy, a critical study of its moral justifications is required. Yet, research on sharing economy from a moral economy perspective is scarce (for exceptions, see Fitzmaurice et al., 2018; Germann Molz, 2013; Mikołajewska-Zajac, 2018; Wahlen and Laamanen, 2017). The moral economy allows for examining the moral justifications of sharing economy practices in general, but more particularly the moral dimensions and politics of householding. The relation between householding - including, but not restricted to, households - and the sharing economy has likewise remained underdeveloped for two main reasons: 1 . due to a general neglect in discussing the historical development of the sharing economy, that is, accepting it as an inherently postmodern, contemporary creation in an individualised neoliberal context, and 2. given the overwhelming concentration of research on commercial applications in the sharing economy, its platforms and business models.

We argue that householding allows for a clearer rooting in the everyday of the sharing economy. Householding is based on its own social and moral principles, which can bridge between the individual and collective lifestyles and practices in the sharing economy that typically 'although shared, are individual in their execution [enactment] 
and spatially bound in households and communities, and temporally in the everyday' (Wahlen and Laamanen, 2015, p. 399). We will focus on the foundational principles of householding next.

\section{The moral economy of householding}

In his treatise on the development of modern markets, Karl Polanyi (2001) elaborated on the tensions between moral human and market institutions. The former, including householding, engage practices of collective sustenance whereas the latter embraces individualised profit-mongering and transactional relationships of exchange. Polanyi (2001) argued that historical forms of economic activity - reciprocity, redistribution and householding - need not be subordinated to one dominant form of the market economy, but be allowed to follow their own institutions and practice. While reciprocity and redistribution as concepts prominently feature in the study of sharing economy (e.g. Botsman and Rogers, 2010), it is only fairly recently that Polanyian analyses have appeared (see Eckhardt and Bardhi, 2016; Pais and Provasi, 2015; Sahakian, 2014, 2017; Wahlen and Laamanen, 2017). With our approach, we wish to further discern householding as an important, yet to date overlooked, element in the functioning of the sharing economy.

Differentiating from reciprocity as 'movements between correlative points of symmetrical groupings' and redistribution as 'appropriational movements toward a center and out of it again' (Polanyi, 1957, p. 250), Polanyi (2001, p. 55) defined householding as 'production for one's own use' based on circularity in a closed network. Founded on the belief in self-sufficiency of a closed group independent from the ruling authority - autarchy - householding further discerns kinship-based, symmetrical reciprocity and centralized, state-driven redistribution. In householding, size, social location, or ideological embedding are peripherical (Polanyi, n.d. in 
Halperin, 1991; Stanfield, 1986). Central is a "communistic" orientation to economic activities that are 'motivated by the necessity of provisioning and production ... carried out with an eye to its direct use by members of the group' (Stanfield, 1986, p. 72) following 'circular flows of resources, goods, and services' in non-capitalist integration (Halperin, 1991, p. 96). While householding is thus circumscribed to independent provisioning groups, several accounts (Gregory, 2009; Halperin, 1991; Sahakian, 2017) consider how householding engages with capitalist and non-capitalist exchanges with 'people working with different livelihood strategies navigate between capitalist and non-capitalist systems' (Sahakian, 2017, p. 47). Yet, householding is neither dominated by market institutions nor its logic of productivity, utility, and profit maximisation.

Householding practices are activities and processes that allocate resources satisfying needs and wants (including strategies managing and coping with everyday life) as well as emphasise social relationships and cultural values of (service) provision (Niehof, 2011; Niehof and Wahlen, 2017). Householding practices are relevant in two particular ways. Firstly, they are organised around mutual dependency and functional similarity between the members who engage in activities that aim at individual and collective livelihood. Secondly, householding practices institutionalise into internalised logics that unify and regulate its members identities in solidaristic interaction. In householding, everyday economic decisions, for instance to downshift, can be based on both a moral judgement as well as necessity, inasmuch as participants are required to make ends meet, develop skills for self-provisioning and self-sufficiency, and reduce consumption (Gibson-Graham et al., 2013). Such everyday, localised, political work and consumption practices offer direct support to sustainable consumption and social sustainability (Holzer, 2006; Wahlen 2018; Wahlen and Laamanen, 2015; Yates, 2018). 
Ultimately, householding fell out of fashion in Polanyi's later published work mainly due to perceived limited generalisability, historicity in the pre-market economy peasant society as well as Polanyi's own general disinterest in the concept (cf. Gregory, 2009; Halperin, 1991). Obviously, Polanyi could not have foreseen how a networked, platform-aided social interaction in the sharing economy could revitalise this concept. Consequently, several contemporary examples on householding practices can be found in the sharing economy: these generally involve community building and joint governance efforts as attempts to create self-sufficient groups on autarchic principles and beliefs on technological platforms (e.g. Wahlen, 2018). In these communities, the functioning of the sharing economy is analogous to a household, where organising production and consumption is based upon mutual dependency, coordination, and temporality in collective sustenance (Felson and Spaeth, 1978), but also ridden with potential issues, such as socially oppressive and problematic relations, vulnerability, exclusion, and emotional indebtedness (Schor et al., 2016). Indeed seeing 'the domestic sphere as a source of safety, fairness and empowerment elide the often-bleak realities of the home' (Fitzmaurice et al. 2018, p. 14).

Scrutinising everyday life and householding as moral economy does not aim at moralising consumption as an individual act, but emphases the moral justifications for economic activity. These include problematising the structural causes for societal injustice; commercial and financial colonialisation of the everyday life; the accelerated work-and-spend cycles the economy depends upon, and the responsibilisation, stigmatisation and victimisation of the rational consumer over the effects of consumption on environmental degradation (cf. Akenji, 2014; Barnett et al., 2008; Fraser, 2016). The everyday politics in moral householding emphasise acts of altruistic, communistic sustenance, and translate to the battles by the economically suppressed 
who attempt to realise 'the possibility that the economy can be a space of ethical action, not a place of submission to "the bottom line" or the "imperatives of capital" (GibsonGraham and Roelvink, 2011, p. 29).

These 'politics of possibility' (Gibson-Graham, 2006) accept that there are genuine alternatives to the market economy, and that its institutions represent only one way of organising an economy (cf. Polanyi, 2001). Contesting the status quo requires mobilising ideas and institutions by reframing commonly accepted "truth" about the economy, envisioning ways various everyday projects aiming for creation and / or renewal of alternative economic models, and activating these. An alternative is moral inasmuch as it, firstly, immediately affects others and the common good (Wilk, 2001), and secondly, makes its fruits accessible, mobilised, and distributed in collectively defined institutions and practices (Cheal, 1989). In the following section, we focus on the mobilisation of moral householding and its impacts on the sharing economy.

\section{Mobilising moral householding in context of the sharing economy}

Mobilising moral householding practices is essential to how moral economy resists capitalism and its ills. By definition, moral householding does not emphasise economic viability or desirability central to the dominant neoliberal economic discourse; instead, economic activities are morally justified when they are socially appropriate. While conceptually the moral economy and householding have found little resonance in studies of contention and mobilisation (Gemici, 2013), we underscore the potential of householding as an act of collective resistance. As Della Porta (2015, p. 138) elaborates, in the neoliberal society, flourishing forms of resistance in popular movements 'emerged as independent from states and with more of a focus on the forms of protest on collective consumption than on labour ... [reacting] to the disruption of everyday life'. 
Disruption of everyday life present unexpected changes in the routines, habitudes, and normalised rhythms that govern everyday lives. Disruptions not only cause distress in affected communities, but also create mobilising grievances that boost collective agency (Borland and Sutton, 2007; Snow and Soule, 2010). Changes in situated understandings of what is right and wrong provide a moral justification to reorganise social and political structures to create new arrangements of daily life (Gemici, 2013; Germann Molz, 2013; Trentmann, 2009). Moral householding as a form of resistance carries several impacts to communities and the collective good. Firstly, there are economic implications for meeting current and future needs through goods and service provision, as well as providing opportunities for sustaining livelihoods. Originally, the sharing economy was to promote sustainability through collaborative consumption of accessing and using dormant resources. This has not prevented neoliberal capitalism to extend to the private areas of life in search for new ways to extract value from dormant resources (Scholz, 2017; Slee, 2015). Indeed, householding time can become a valuable source of profit which shifts householding from the social sphere into the economic sphere on commercial sharing economy platforms.

Secondly, householding helps build social cohesion and support inclusion in communities. Sharing is seen as the reification of the innate pro-social, solidaristic tendencies in human beings. Belk (2010) exemplifies this in mothering and family life whereby sharing links us to others in the group by the way of altruistic, non-material / social, and qualitatively and quantitatively indefinite reciprocities (see also Sahlins, 1972). Sahakian (2017) examines reciprocity in the social and solidarity economy where kinship takes a more abstract, ideational dimension when compared to the perspective of kinship as based on consanguinity. The social desirability of interactions and membership in the moral household economy (Niehof and Wahlen, 2017) should 
not be misinterpreted as householding practice necessarily always being positive: a prosocial sharing perspective often downplays conflicts in mutual dependence and in the community's relations to its environments.

Thirdly, householding aligns with the ecological principles of degrowth, relying on production for use rather than for exchange and sustainable development underscoring well-being of all, including the natural environment. The sharing economy is frequently connected to sustainability debates: the social desirability of increased awareness, confrontation with the impact of human activity on environments and societies as well as the quality of life for current and future generations (Heinrich, 2013). Finally, householding is political where it resists neoliberal, monetised, and consumerists principles seeping into local communities (Laamanen et al., 2015; Lorek and Fuchs, 2013; Schor, 2010; Soper, 2007). The goals of mobilisation in everyday life are related to remedial and transformative impact on individual, collective, and environmental well-being, social justice, and sustainability. As we have illustrated above, householding connects to collective action in everyday mobilisation, thereby moving beyond social connectivity and reciprocities. A political perspective to sharing and collaborative consumption considers mobilisation connected to private, continuous and lifestyle-based collective action (Wahlen and Laamanen, 2015). In the sharing economy, we can see activities such as calls and activities towards rebuilding and reclaiming common resources through forms of joint ownership, collaborative relationships, and joint governance mechanisms reflecting autarchic principles of householding (Balaram, 2016; de Angelis, 2017).

In the following part, we illustrate mobilisation and impacts of moral householding by using the example of timebanking. Timebanking aims to provide a viable, communal alternative to commercial markets at the intersection of community, 
currency, and morality (cf. Bloch and Parry, 1989). Timebanks are attempts to create (partial) independence from the mainstream economy in contexts where markets and public provision are functioning less satisfactorily. Timebanks can be situated between informal markets, local community exchange and voluntary work (North, 2007; Schroeder et al., 2011; Seyfang, 2004). Our insights derive from a close reading of debates about complementary, local currencies as well as first-hand experience in timebank participation. This in situ experience emerges from the first author's participation in the exchanges and organising of "The Helsinki Timebank" ongoing since 2015. The collected ethnographic data include interviews with timebank activists, observations of events and meetings, and various archival materials and documents. Examining previous research in conjuncture with empirical data provides insights in householding practices that resonate within the larger confides of a moral sharing economy.

\section{Recognising householding in alternative currencies: the example of timebanking}

In modern societies, money dominates the ordering of economic collaboration. With the establishment of modern currencies, a measure of parity emerged, shifting the focus from communal self-sufficiency and production to use - elements of householding - to prosperity founded on the pursuit of individual gain at the cost of the community (e.g. Bloch and Parry, 1989). It is on this level of community that a threat to moral order emerges with the introduction of money. Maurer (2006) argues this to be the great transformation that liberated individuals from the yoke of communality. Monetary exchange exists between the individual's transient acquisitive activities and the generation of a more persistent social order, both feeding into one another (Bloch and Parry, 1989). The continuing economic crisis and austerity, however, have brought 
dramatic changes to livelihoods. Combined with a disillusion about equitable participation in the market, maximisation through accumulation and hyper-consumption loses resonance.

In an economy based on the principles of householding, production and consumption are moderated by mechanisms other than price, availability, and yield. Alternative currencies are one prominent attempt to "re-communalise" the economic transactions as means, and community as an end, by bounding the exchange and valuation of skills, competences, and material resources in the social, spatial, and temporal order of the community (cf. Laamanen et al., 2015, forthcoming). Central to complementary currencies is a change in the underlying social order as well as relating to the practices of valuation of provision and consumption (e.g. Alhojärvi et al., 2015; Dittmer, 2013; Gregory, 2014; Joutsenvirta, 2016; Laamanen et al., 2015, forthcoming; North, 2007). One such alternative mechanism is time. When individuals are faced with efficiency demands and time pressures in the various spheres of everyday life, time essentially becomes a scarce resource, influencing the physical, economic and social relations around us - how we work, buy, socialise, organise, or just function as humans (see Schor, 2010).

Below, we evaluate timebanking as a tool to mobilise householding based on its particular practices: "establishing an alternative valuation", "building grassroots capacity", "reforming neoliberal subjects and institutions", and "contributing to sustainability".

\subsection{Establishing an alternative valuation}

Valuation in timebanks is dissociated from the hegemonic understandings of equality correlated with money, such as represented in the idea of monetary currency as a radical leveller of hierarchical relations (Marx, 1961, quoted in Bloch and Parry, 1989, p. 6). 
Contrastingly, in timebanking, everyone's input is exchanged at par, appraised in time used, and treated as equally valuable. The morality in timebanking relates to a general rejection of subjecting participants and their competences to a valuation that 1 . focuses on efficiency (including time used and return on "investment"; 2. dissolves communality, and 3. prioritises economic growth and wealth accumulation (cf. Boyle, 2003; Collom, 2011; Gregory 2014; Joutsenvirta, 2016; Laamanen et al., 2015; Seyfang, 2004).

Following our understanding of householding practices outlined above, householding in timebanking relates to meeting immediate needs, providing social cohesion, and institutionalising means of resilience to localities through the use of communal resources and competences. Contextually, time transforms from a scarce economic resource to a conduit for community resourcing and competence building. As a valuation mechanism time is both transparent and affiliating: one hour of work for any person in the community results in an hour of work receivable from anyone in the community. Even further, timebanking can be considered as an intertwinement of communal production and consumption creating belongingness, networks, and empowerment, while also forging community boundaries and self-sufficiency around participants building positive mutual dependency.

Different from the commercial approach of the sharing economy which becomes means for further exploitation of resources outside of a formal employment relationship ('free work'; Fleming, 2014; Zwick et al., 2008), timebanks can to some degree be resilient to these developments, since 'the core of time banking [sic] practice rests on the use-value of time, referring to the benefit to be found in a commodity during its consumption' (Gregory, 2014, p. 178). Thus, time only has meaning and value when it 
becomes utilised, that is, consumed as the work is rendered and timebanking activities performed.

Furthermore, time as currency is an expression of the general goals and values of the community: equity and inclusion. Timebanking activists interviewed during our fieldwork push the transience of the community currency even further. They envision a critical appreciation of the currency in building meaningful relations rather than instrumental ones or value hoarding similar to the monetary practices of the consumer society, and, ultimately, teaching participants to find a way out from relying on any mechanisms of exchange (Fieldnote, March 2015). They therefore consider the community currency as a tool for transforming exchange practices towards fundamentally communistic provision: from needing an intermediary mechanism (of currency) to a community functioning without the need or inclusion of one where members' can request from the community based on their needs and give according to capacity.

\subsection{Building grassroots capacity}

Householding is the epitome of an economy produced by people in a democratic process that gives them capacity and power over their own condition. Mobilisation of householding in timebanking rests upon a moral challenge to institutionalised cultural and economic practices. The literature on timebanking places a strong emphasis on bottom-up grassroots attempts to build new institutions and common infrastructure (Douthwaite, 1996). Laamanen et al. (forthcoming) illustrate the prominence of grassroots prefigurative politics over centralised, bureaucratised policy-making. For instance, the community has for its nine-year existence steered clear of institutional influence by not registering any official organisational form. This is motivated by a fear of external hierarchical order being introduced in the community which could replace 
the internal horizontal one. Independence from outside rules and regulations is deemed necessary for truly democratic decision-making. Yet, choosing not to operate as a registered charity or an association has caused several issues related internally to power wielding amongst the participants and externally to interactions with the established forms of order in the society.

The main benefit of grassroots capacity to the participants of timebanking may not be how much social or environmental impact is reduced through the activities, but how (much) the localised economies can generate mechanisms and structures to survive independently, at least for some time span in case of economic crisis or even natural disasters (Gregory, 2014; Simms, 2008). While capacity provides meaning to householding, we can see here a justification to claims that householding exist in the fault lines of the market and the non-market (Gregory, 2009). Some researchers (Gregory, 2014; Laamanen et al., 2015) argue that local provision may be utilised for replacing public and market services as community resilience can easily be used to justify reductions of public welfare provision given that communities endure on their own. This is where neoliberal responsibilisation comes in close resemblance with autarchic practices of householding. When (and if) householding replaces some dysfunctions of the public sector or the market, it can easily mutate from a movement against the current neoliberal politico-economic system to one working along the system's standards. Gregory (2014) argues that timebanking is both a response to and a mechanism reproducing the ills of capitalism, and elaborates on this argument in the context of the "Big Society" which in its native UK-context refers to the neoliberal responsibilisation of communities, whereby 'time banking [sic] can be used to engage (and monitor) citizens and facilitate community resilience' (Gregory, 2014, p. 176). 
Problematically, the community carries a double responsibility as it firstly reacts to austerity measures, such as local public service cuts, by producing services themselves, and secondly, is made responsible to producing these services as a new public policy (such as the Big Society) renders this situation normality. Moreover, it aligns with the classical perception of householding as reproductive work for sustaining and stabilising the regime of capital accumulation (Gibson-Graham, 1996).

\subsection{Reforming neoliberal subjects and institutions}

Timebanking communities may fall prey to various problems with the deep-rooted socialisation of participants as "neoliberal subjects", as well as with dealing with formal institutions. Similar to Schor and her co-authors' (2016) finding on timebanking activities as a form of charity, some participants in our timebank are not reciprocating. Their moral justification of this way of participating is that they want to help people, but have no need for receiving from the timebank. In effect, these members discuss their surpluses in community meetings with pride, potentially trying to generate distinction towards themselves (similarly to Schor et al.'s informants). Generating too large surpluses (or deficits) is in fact against the formalised community rules that state that a maximum of 50 currency units account balance in surplus or deficit is accepted. Yet, the community rarely enforces sanctions, and thus far, never with members in surplus.

Some research (Papaoikonomou and Valor, 2016; Schor et al., 2016) report participants evading requesting or offering services in timebanks, if the services are perceived as qualitatively better or more valuable to the provider when performed through the market. As such, meaningful connections between compatible members or relational matching might be missing (Germann Molz, 2013; Schor et al., 2016). In the timebank focal to our empirical efforts, the main internal tension relates to the expectations of participation in collective governance. Explicitly, the community claims 
to be open, expecting the membership to steer communally; yet implicitly power is wielded by a few central individuals when it comes to decisions of how to mobilise the community (Laamanen et al., forthcoming).

Joutsenvirta (2016, p. 27) recounts the Nordic timebank as 'focused on creating a new institutional position for TBs which was complementary or parallel to existing institutions without assaulting the pre-existing institutions'. Local and national governments are perceived to side with and submit to the power of neoliberalism, and thus deemed to have failed to implement effective social and environmental policies for sustainability (see also Kallis, 2011). The implications to local communities are significant, but challenging them head-on seldom works. In context of our Finnish timebank, members were shocked by the national government's tax guidelines, according to which any professional work in the community needs to be valued as taxable income. Without going into depth (for details, see e.g. Joutsenvirta, 2016; Laamanen et al., forthcoming), this decision was a significant blow to timebanking. Although the implementation of this regulation was not very clear (e.g. how to determine the taxable value of a trade in time units), the impact of the decision led to increased confusion and anxiety among the timebank membership which began to shrink in numbers and led to fewer exchanges being made.

Finally, there is some overall similarity with our timebank and the case described by Schor et al. (2016) with regards to professional services. Yet, the communally accepted principle of equal valuation (combined with the challenges of formal taxability of professional services) in our timebank sets it apart from theirs where the withdrawal of professional services was due to their high valuation in the market. As such, while there is a similar effect, the root cause is different. 


\subsection{Contributing to sustainability}

A traditional view of production and consumption highlights the demonstrative, constructive, and affiliate features of acting in the consumer culture (e.g. through identity creation, expression of self, and association with a social reference group); in timebanking, the collective experience takes primacy over the individual one. Beyond human contact, sharing competences in a timebank allows people to meet psychological needs, such as recognition, belonging, self-esteem and sense of purpose in other ways than for instance conspicuous consumption. Social issues of strengthening the social grid as well as building community relations and capacities are major drivers of the moral justification of sharing and communality in timebanks. Seyfang and Longhurst (2013) locate timebanks in the social corner of the traditional triangle of sustainability in a mapping of alternative currencies based on their stated goals. Laamanen et al. (2015) found the social embedding to be the case for one out of three timebank initiatives they compared, whereas the other two were explicitly oriented towards changing the monetary system (an economic orientation).

Timebanks are often promoted as practical vehicles for raising people's awareness about sustainability issues (Seyfang and Longhurst, 2013). The expected positive environmental potentials are manifold. Meaningful participation through social interaction, rather than through material consumption, allows households to meet their needs, and simultaneously reduces the ecological footprints of individuals and neighbourhoods (Dittmer, 2013; Douthwaite, 1996; Ryan-Collins et al., 2008; Seyfang and Longhurst, 2013). There is some evidence that community currencies stimulate local economic activity in the sense of householding that reduces the need to import products from other regions, thereby bulwarking environmental sustainability through reduced transport and pollution (Michel and Hudon, 2015, p. 167). However, one 
should not count on too much impact, at least not regarding direct effects. Participation in timebanks only accounts for a small amount of people's work and interaction with the environment, thus, of their general use of resources. The lack of assessment of environmental benefits makes it difficult to draw any definite conclusions and thus gives little support to the argument that they contribute to environmental sustainability (Michel and Hudon, 2015). Further assessment of environmental effects of timebanks would be interesting and necessary.

Larger opportunities to promote sustainability lie in the possibility to alter structures, mind-sets and moral justifications of alternative economic activities. This ultimately aims to influence personal and collective politics. When set within the larger confides of the neoliberal politics of individualisation and responsibilisation, the community work that timebanking stands for is political in form and consequence, even if the political motivation of participants or an overarching ideology in the movement may not be easy to establish.

\section{Discussion and conclusion: Towards a moral sharing economy}

In this paper, we elaborate on the practices that moral foundation of householding can bring to the debate on the sharing economy. Neoliberal politics and practices promote individual responsibility over their own and their families' condition, further stimulating the (perceived) need to work and spend. Our view on the sharing economy is through the lenses of householding as a transformative approach to distributive justice, more sustainable production and consumption, and self-sufficiency providing real alternatives to neoliberal orthodoxy. Householding thus appears as a communistic and commonsbased alternative to the commercialised sharing economy. Our thinking here echoes Sayer (2007) who views that moral constitution of economic practice rests on relations of provision as well as on the normative assumptions of rights and responsibilities. 
Aligned with the general assumption that the sharing economy is inherently better justified morally, more sustainable, and more inclusive than the mainstream economy, we have examined the degree to which householding as sharing economy practices can be understood in these moral terms.

We envision householding practices to reveal central problems that neoliberalism imposes on localities: a householding perspective is a useful tool for understanding the move away from a neoliberal platform-based sharing economy featuring as the mainstay in current research and policy. Through the disruption of everyday life, localised production and consumption has become a means of resisting neoliberalism. Householding practices build upon the moral and ethical conviction through which self-sufficiency and more autonomy in local groups can address challenges of political, economic, social, and ecological sustainability (cf. Lorek and Fuchs, 2013; Seyfang and Longhurst, 2013). To these ends, our example of timebanking is illustrative of the various householding practices emphasising personal and social services in community. Time as a valuation mechanism functions to share wealth by increasing community skills and self-sufficiency. The politico-economic orientation of timebanks addresses issues of power, conflict, and social justice, the economic, political, and social goals which are the greatest attraction (a finding similar to other alternative exchange systems; see Germann Molz, 2013). Only a few studies explicitly identify environmental outcomes (Seyfang and Longhurst, 2013; Michael and Hudon, 2015). Similarly, previous research (e.g. Laamanen et al., 2015; Papaoikonomou and Valor, 2016) has shown that some economic instrumentality / necessity and political conviction drive the motivation to participate in these communities.

In the way we conceptualise householding in this paper, we envision the recognition of moralities in householding as a more general cultural change carrying 
various potential societal impacts for the provision of material and relational sustenance as well as for communal resilience and independence, while respecting the social and ecological environment. From a moral householding perspective, sharing can be, at the same time, a lifestyle choice and an ethical commitment for attempts to forego and resist capitalism and state power (cf. Halperin, 1991; Polanyi, 2001), as well as a mechanism of meeting everyday needs. For instance, in our example of timebanking, householding can simultaneously be a political project for activists and new economy builders as well as a necessity project to its users. However, both are influenced and amplified by networking technologies that allow the community to reach and include larger areas, the likeminded (kin) as well as strangers.

The 'politics of possibility' in timebanking include a myriad of (contradictory) ideas, issues, rationales and framings (e.g. Laamanen et al., 2015; Seyfang and Longhurst, 2013). These mobilise householding practices to build self-sufficiency and provision, which represents the ultimate moral outcomes of timebanking action. Promoting a collective pool of a wide variety of skills and competences contributed by a community, and the altruist meaning of economic interaction is dynamic and contradictory: it provides both promise and utopia of a sustainable alternative moral logic, while being wedged in the governing capitalist logic. Therefore, householding may potentially fall prey to new politico-economic policies (such as the "Big Society") that eventually aim to substitute public services with community efforts.

The boundaries between production and consumption are deconstructed in several postmodern critiques, such as those outlining prosumption and the commons (e.g. de Angelis, 2017; Ritzer and Jurgenson, 2010; Røpke. 1999; Toffler, 1980). In a similar vein, the moral household economy considers production and consumption to be divorced from their linear representations in the orthodox capitalist discourse. A true 
sustainable consumer culture builds upon a sustainable everyday: it is in this everyday space where renunciation from the unsustainable framework of neoliberal markets materialises. Moral householding communities not only mobilise people and resources, but also develop an alternative moral judgement that moves beyond social connections, reciprocities and resource flows to challenging the status quo through mobilised resistance. As opposed to commercial sharing, householding is pro-social and political with the potential to change the sharing economy into a more sustainable and just direction.

\section{References}

Akenji, Lewis. 2014. "Consumer scapegoatism and limits to green consumerism." Journal of Cleaner Production 63: 16-23. doi: 10.1016/j.jclepro.2013.05.022

Alhojärvi, Tuomo, Sanna Ryynänen, Niklas Toivakainen, and Ruby van der Wekken, R. 2015. "Solidaarisuustalous." In Talouden uudet muodot [New Forms of the Economy], edited by Mikko Jalonen and Tiina Silvasti, 210-230. Helsinki: Into.

Amable, Bruno. 2011. "Morals and politics in the ideology of neo-liberalism." SocioEconomic Review 9 (1): 3-30. doi:10.1093/ser/mwq015

Balaram, Brhmie. 2016. Fair Share: Reclaiming Power in the Sharing Economy [RSA publication, January 2016]. Retrieved from https://www.thersa.org/discover/publications-and-articles/reports/fair-sharereclaiming-power-in-the-sharing-economy/\#

Bardhi, Fleura and Giana Eckhardt. 2012. "Access-based consumption: the case of car sharing." Journal of Consumer Research 39(4): 881-898. doi:10.1086/666376

Barnett, Clive, Nick Clarke, Paul Cloke, and Alice Malpass. 2008. "The elusive subjects of neo-liberalism.” Cultural Studies 22 (5): 624-653. doi:10.1080/09502380802245902

Belk, Russel. 2010. "Sharing.” Journal of Consumer Research 36 (5): 715-734. doi:10.1086/612649

Bloch, Maurice, and Jonathan Parry. 1989. "Introduction: money and the morality of exchange." In Money \& the Morality of Exchange, edited by Jonathan Parry, \& Maurice Bloch, 1-32. Cambridge, UK: Cambridge University Press.

Bolton, Sharon C., and Knut Laaser. 2013. "Work, employment and society through the lens of moral economy." Work, Employment and Society 27 (3): 508-525. doi:10.1177/0950017013479828

Borland, Elizabeth, and Barbara Sutton. 2007. "Quotidian disruption and women's activism in times of crisis, Argentina 2002-2003." Gender and Society 21 (5): 700-722. doi:10.1177/0891243207306383

Botsman, Rachel, and Roo Rodgers. 2010. What's Mine is Yours: The Rise of Collaborative Consumption. New York: HarperCollins. 
Boyle, David. 2003. "The new mutualism and the meaning of time banks." Local Economy 18 (3): 253-270. doi:10.1080/0269094032000111048b

Cheal, David. 1989. "Strategies of resource management in household economies: moral economy or political economy?" In: R. Wilk (ed.), The Household Economy: Reconsidering the Domestic Mode of Production (Boulder/San Francisco/London: Westview Press, 1989), 11-23.

Cheng. Mingming. 2016. "Sharing economy: a review and agenda for future research." International Journal of Hospitality Management 57: 60-70. doi: 10.1016/i.iihm.2016.06.003

Collom, Ed. 2011. "Motivations and differential participation in a community currency system: the dynamics within a local social movement organization." Sociological Forum 26 (1): 144-168.

de Angelis, Massimo. 2017. Omnia sunt Communia. London, UK: Zed Books.

della Porta, Donatella. 2015. Social Movements in Times of Austerity: Bringing Capitalism Back into Protest Analysis. Cambridge: Polity.

Douthwaite, Richard. 1996. Short Circuit: Strengthening Local Economies for Security in an Unstable World. Totnes: Green Books.

Dittmer, Kristofer. 2013. "Local currencies for purposive degrowth? A quality check of some proposals for changing money-as-usual." Journal of Cleaner Production 54: 3-13. doi: 10.1016/j.jclepro.2013.03.044

Eckhardt, Giana, and Fleura Bardhi. 2016. "The relationship between access practices and economic systems." Journal of the Association for Consumer Research 1(2): 210-225. doi:10.1086/684684

Felson, Marcus, and Joe E. Spaeth. 1978. "Community structure and collaborative consumption: a routine activity approach." American Behavioral Scientist 21 (4): 614-24. doi:10.1177/000276427802100411

Fitzmaurice, Connor J., Isak Ladegaard, William Attwood-Charles, Mehmet Cansoy, Lindsey B. Carfagna, Juliet B. Schor, and Robert Wengronowitz. 2018. "Domesticating the market: moral exchange and the sharing economy." SocioEconomic Review. Advance online publication. doi:10.1093/ser/mwy003

Fleming, Peter. 2014. Resisting Work. The Corporatization of Life and its Discontents. Philadelphia: Temple University Press.

Frenken, Koen, and Juliet Schor, 2017. "Putting the sharing economy into perspective." Environmental Innovation and Societal Transitions 23 (June): 3-10. doi:10.1016/j.eist.2017.01.003

Fraser, Nancy. 2016. “Contradictions of capital and care.” New Left Review 100: 99117.

Germann Molz, Jennie. 2013. "Social networking technologies and the moral economy of alternative tourism: the case of couchsurfing.org." Annals of Tourism Research 43: 210-230. doi:10.1014/j.annals.2013.08.001.

Gemici, Kurtuluş. 2013. "Moral economy redux: social protests in turkey after the 2001 economic crisis." Mobilization: An International Quarterly 18 (2): 143-160.

Gibson-Graham, J. K. 1996. The End of Capitalism (as We Knew it). Minneapolis: University of Minnesota Press.

Gibson-Graham, J. K. 2006. A Postcapitalist Politics. Minneapolis: University of Minnesota Press.

Gibson-Graham, J. K., and Gerda Roelvink. 2011. "The nitty gritty of creating alternative economies." Social Alternatives 30 (1): 29-33. 
Gibson-Graham, J. K., Jenny Cameron, and Steven Healy. 2013. Take Back the Economy: An Ethical Guide for Transforming Our Communities. Minneapolis: University of Minnesota Press.

Götz, Norbert (2015) “"Moral economy': its conceptual history and analytical prospects." Journal of Global Ethics 11(2): 147-162. doi:10.1080/17449626.2015.1054556.

Gregory, Chris. 2009. "Whatever happened to householding?" In Market and Society: The Great Transformation Today, edited by Chris Hann and Keith Hart, 133159. Cambridge: Cambridge University Press.

Gregory, Lee. 2014. "Resilience or resistance? Time banking in the age of austerity." Journal of Contemporary European Studies 22 (2): 171-183. doi:10.1080/14782804.2014.902366

Halperin, Rhoda H. 1991. "Karl Polanyi's concept of householding - resistance and livelihood in an Apalachian region." Research in Economic Anthropology 13: 93-116.

Harvey, David. 2005. A Brief History of Neoliberalism. Oxford: Oxford University Press.

Heinrichs, Harald. 2013. "Sharing economy: a potential new pathway to sustainability". GAIA 22 (4): 228-231. doi:10.14512/gaia.22.4.5

Holzer, Boris. 2006. "Political consumerism between individual choice and collective action: social movements, role mobilization and signalling." International Journal of Consumer Studies, 30(5): 405-415. doi:10.1111/j.14706431.2006.00538.x

Jalas, Mikko and Jouni Juntunen, 2015, "Energy intensive lifestyles: time use, the activity patterns of consumers, and related energy demands in Finland." Ecological Economics, 113: 51-59. doi:10.1016/j.ecolecon.2015.02.016

Joutsenvirta, Maria. 2016. "A practice approach to the institutionalization of economic degrowth." Ecological Economics, 128: 23-32. doi: 10.1016/j.ecolecon.2016.04.006

Kallis, Giorgis. 2011. "In defence of degrowth.” Ecological Economics 70 (5): 873-880. doi:10.1016/j.ecolecon.2010.12.007

Laamanen, Mikko, Marcos Barros, and Gazi Islam. 2018. "Collective representation on collaborative economy platforms." In Contemporary Collaborative Consumption, edited by Isabel Silva Cruz, Rafaela Ganga and Stefan Wahlen. Heidelberg: Springer. doi:10.1007/978-3-658-21346-6_3

Laamanen, Mikko, Sanne Bor, and Frank den Hond. forthcoming. "The dilemma of organization in social movement initiatives." In Organization Unbound, edited by Göran Ahrne and Nils Brunsson. Cambridge: Cambridge University Press.

Laamanen, Mikko, Stefan Wahlen, and Mario Campana. 2015. "Mobilising collaborative consumption lifestyles: a comparative frame analysis of time banking." International Journal of Consumer Studies 39(5): 459-467. doi:10.1111/ijcs. 12190

Ladegaard, Isak. 2018. "Hosting the comfortably exotic: cosmopolitan aspirations in the sharing economy." The Sociological Review, 66(2): 381-400. doi:10.1177/0038026118758538

Lorek, Sylvia, and Doris Fuchs. 2013. "Strong sustainable consumption governance precondition for a degrowth path?" Journal of Cleaner Production 38 (1): 3643. doi:10.1016/j.jclepro.2011.08.008

Luxton, Meg. 2006 "Friends, neighbours, and community: a case study of the role of informal caregiving in social reproduction." In Social Reproduction, edited by 
Kate Bezanson and Meg Luxton, 263-292. Montreal and Kingston: McGillQueen's University Press

Maurer, Bill. 2006. "The anthropology of money." Annual Review of Anthropology, 35: 15-36. doi:10.1146/annurev.anthro.35.081705.123127

Michel, Arnaud, and Marek Hudon. 2015. "Community currencies and sustainable development: a systematic review." Ecological Economics 116: 160-171. doi:10.1016/j.ecolecon.2015.04.023

Mikołajewska-Zając, Karolina. 2018. "Terms of reference: the moral economy of reputation in a sharing economy platform." European Journal of Social Theory 21 (2):148-168. doi:10.1177/1368431017716287.

Moisander, Johanna K., Claudia Groß and Kirsi Eräranta. 2018. "Mechanisms of biopower and neoliberal governmentality in precarious work: Mobilizing the dependent self-employed as independent business owners." Human Relations, 71 (3): 375-398. doi:10.1177/0018726717718918

Niehof, Anke. 2011. "Conceptualizing the household as an object of study." International Journal of Consumer Studies 35 (5): 488-497. doi:10.1111/j.14706431.2011.01026.x

Niehof, Anke, and Stefan Wahlen. 2017. "Moralities of sharing and caring. Gender and food in the moral household economy." In Gendered Food Practices. From Seed to Waste (Yearbook of Women's History, Vol. 36), edited by Bettina Bock and Jessica Duncan. Amsterdam: Verloren.

North, Peter. 2007. Money and Liberation. Minneapolis: University of Minnesota Press.

Pais, Ivana, and Giancarlo Provasi. 2015. "Sharing economy: a step towards the reembeddedness of the economy?" Stato e Mercato, 105: 347-377.

Papaoikonomou, Eleni, and Carmen Valor. 2016. "Exploring commitment in peer-topeer exchanges: the case of timebanks." Journal of Marketing Management 32(13-14): 1333-1358. doi: 10.1080/0267257X.2016.1177578

Polanyi, Karl. 1957. "The economy as instituted process." In Trade and Market in the Early Empires. Economies in History and Theory, edited by Karl Polanyi, Conrad M. Arnsberg and Harry W. Pearson, 243-270. Glencoe: The Free Press.

Polanyi, Karl. 2001. The Great Transformation. The Political and Economic Origins of Our Time. Boston: Beacon Press.

Richardson, Lizzie. 2015. "Performing the sharing economy." Geoforum 67: 121-129. doi:10.1016/j.geoforum.2015.11.004

Ritzer, George, and Nathan Jurgenson. 2010. "Production, consumption, prosumption." Journal of Consumer Culture 10 (1): 13-36. doi:10.1177/1469540509354673

Røpke, Inge. 1999. "The dynamics of willingness to consume." Ecological Economics, 28(3), 399-420. doi:10.1016/S0921-8009(98)00107-4

Ryan-Collins, Josh, Lucie Stephens and Anna Coote. 2008. The New Wealth of Time: How Timebanking Helps People Build Better Public Services. London: New Economics Foundation.

Sahakian, Marlyne. 2014. "Complementary currencies: what opportunities for sustainable consumption in times of crisis and beyond?", Sustainability: Science, Practice and Policy, 10(1): 4-13. doi:10.1080/15487733.2014.11908121

Sahakian, Marlyne. 2017. "Toward a more solidaristic sharing economy: examples from Switzerland." In Social Change and the Coming of Post-Consumer Society: Theoretical Advances and Policy Implications, edited by Maurie J Cohen, Halina Szejnwald Brown and Philip J Vergragt, 43-60. Abingdon: Routledge.

Sahlins, Marshall. 1972. Stoneage Economics. Chicago: Aldine Atherton. 
Sayer, Andrew. 2007. "Moral economy as critique." New Political Economy, 12(2): 261-270. doi:10.1080/13563460701303008

Scholz, Trebor. 2017. Uberworked and Underpaid: How Workers are Disrupting the Digital Economy. Cambridge: Polity.

Schor, Juliet. 2010. Plenitude. London: Penguin Books.

Schor, Juliet, Connor Fitzmaurice, Lindsay B. Carfagna, Will Attwood-Charles, and Emily Dubois Poteat. 2016. "Paradoxes of openness and distinction in the sharing economy." Poetics 54: 66-81. doi: 10.1016/j.poetics.2015.11.001

Schroeder, Rolf F.H., Yoshihisa Miyazaki, and Marie Fare. 2011. "Community currency research: an analysis of the literature." International Journal of Community Currency Research 15 (A): 31-41.

https://ijccr.files.wordpress.com/2012/04/ijccr-2011-schroeder.pdf

Seyfang, Gill. 2004. "working outside the box: community currencies, time banks and social inclusion." Journal of Social Policy 33 (1): 49-71. doi: $10.1017 / \mathrm{S} 0047279403007232$

Seyfang, Gill, and Noel Longhurst. 2013. "Growing green money? Mapping community currencies for sustainable development.” Ecological Economics 86: 65-77. doi:10.1016/j.ecolecon.2012.11.003

Simms, Andrew. 2008. Nine Meals from Anarchy: Oil Dependence, Climate Change and the Transition to Resilience. Schumacher Lecture, New Economics Foundation.

Slee, Tom. (2015). What's Yours is Mine. Against the Sharing Economy. New York: OR Books.

Snow, David A., and Sarah A. Soule. 2010. Primer on Social Movements. New York: W. W. Norton.

Soper, Kate. 2007. "Re-thinking the 'good life': the citizenship dimension of consumer disaffection with consumerism". Journal of Consumer Culture 7 (2): 205-229. doi:10.1177/1469540507077681

Spangenberg, Joachim H. and Sylvia Lorek. 2002. "Lebensstandardmessungen einschließlich nicht-marktlicher Dienstleistungen.” In Die Zukunft von Dienstleistungen [The Future of Services], edited by Gerhard Bosch, Peter Hennicke, Josef Hilbert, Kora Kristof and Gerhard Scherhorn, 455-481. Frankfurt: Campus.

Stanfield, James Ronald. 1986. The Economic Thought of Karl Polanyi-Lives and Livelihood. New York: Palgrave Macmillan.

Stephany, Alex. 2015. The Business of Sharing. Making it in the New Sharing Economy. Basingstoke: Palgrave Macmillan

Thompson, E. P. 1966. The Making of the English Working Class. New York: Vintage.

Thompson, E. P. 1971. "The moral economy of the English crowd in the eighteenth century." Past \& Present 50(1): 76-136. doi: 10.1093/past/50.1.76

Toffler, Alvin. 1980. The Third Wave: The Classic Study Of Tomorrow. New York: Bantam.

Trentmann, Frank. 2009. "Disruption is normal: blackouts, breakdowns and the elasticity of everyday life." In Time, Consumption and Everyday Life: Practice, Materiality and Culture, edited by Elizabeth Shove, Frank Trentmann and Richard Wilk, 67-84. Oxford: Berg.

Wahlen, Stefan and Mikko Laamanen. 2015. "Consumption, lifestyle and social movements." International Journal of Consumer Studies 39(5): 397-403. doi:10.1111/ijcs. 12237 
Wahlen, Stefan and Mikko Laamanen. 2017. "Collaborative consumption and sharing economies." In Routledge Handbook on Consumption, edited by Margit Keller, Bente Halkier, Terhi-Anna Wilska, \& Monica Truninger, 94-105. Oxford: Routledge. doi:10.4324/9781315675015.ch9

Wahlen, Stefan. 2018. "Foodsharing: Reflecting on individualised collective action in a collaborative consumption community organization." In Contemporary Collaborative Consumption, edited by Isabel Silva Cruz, Rafaela Ganga and Stefan Wahlen, 57-75. Heidelberg: Springer. doi:10.1007/978-3-658-21346-6_4

Wilk, Richard. 2001. "Consuming morality." Journal of Consumer Culture 1(2): 245260. doi:10.1177/146954050100100211.

Zwick, Detlev, Samuel K. Bonsu and Aron Darmody. 2008. "Putting consumers to work: 'co-creation' and new marketing govern-mentality." Journal of Consumer Culture 8(2): 163-196. doi:10.1177/1469540508090089

Yates, Luke. 2018. "Sharing, households and sustainable consumption." Journal of Consumer Culture. 18 (3):433-452. doi:10.1177/1469540516668229 